\title{
PERKEMBANGAN KAJIAN ASTRONOMI ISLAM DI ALAM MELAYU
}

\author{
Susiknan Azhari*
}

\begin{abstract}
Nowadays, the presence of Islamic astronomy is very important because in some ways it still needed by Muslim countries. Therefore, this article attempts to elaborate the recent development of Islamic astronomy in the Malay world especially in Indonesia and Malaysia. This article also will describe the contribution of early figures i.e. Ahmad al-Fathani and Sheikh Tahir Jalaluddin. For the future needs aims to build mutually beneficial cooperation between Indonesia and Malaysia in order to promote the Islamic astronomy in the world.
\end{abstract}

Keywords: Islamic astronomy, Indonesia, Malaysia

\section{PENDAHULUAN}

Astronomi Islam atau astronomi Arab boleh disebut juga ilmu Falak atau ilmu hisab merupakan salah satu ilmu keislaman yang dilupakan. Padahal ilmu ini telahpun dikembangkan oleh ilmuwan-ilmuwan Muslim sejak abad pertama Hijrah. Bukan hanya untuk pengembangan ilmu sahaja, tetapi juga, dan ini lebih

\footnotetext{
Profesor Pelawat Akademi Pengajian Islam Universiti Malaya Kuala Lumpur Malaysia dan Guru Besar Fakultas Syariah Universitas Islam Negeri Sunan Kalijaga Yogyakarta-Indonesia
} 
penting, untuk kepentingan praktis menjalankan perintah-perintah agama yang sangat berkaitan dengan waktu, seperti solat, puasa, dan haji. Dalam abad pertengahan, perkembangan astronomi Islam menunjukkan majunya peradaban Islam dengan lahirnya tokoh-tokoh besar.

Selanjutnya, dengan astronomi Islam setiap Muslim dapat memastikan ke mana arah kiblat untuk suatu tempat di permukaan bumi yang jauh dari Mekah. Dengannya pula setiap Muslim dapat mengetahui waktu solat sudah tiba atau matahari sudah terbenam (ghurūb) untuk berbuka puasa. Dengannya juga orang yang melakukan rukyah dapat mengarahkan pandangan ke posisi hila $\vec{l}$ yang lebih mendekati ketepatan.

Dengan demikian, astronomi Islam atau ilmu hisab dapat mendatangkan keyakinan kepada setiap Muslim dalam melakukan ibadah, sehingga ibadahnya akan lebih mantap. Pada masa sekarang ini kehadiran astronomi Islam adalah sangat penting, bukan sahaja kerana dalam beberapa hal tetap diperlukan tetapi lebih dari itu ianya juga memiliki makna yang sangat penting dalam menghargai peradaban Islam. Oleh kerana itu tulisan ini ingin melihat sejauhmana perkembangan kajian astronomi Islam di dunia Melayu dengan memfokuskan kajian di Indonesia dan Malaysia.

\section{SEJARAH ASTRONOMI ISLAM DAN LITERATUR- LITERATUR YANG BERKEMBANG DI ALAM MELAYU}

Dalam khazanah intelektual Islam klasik astronomi Islam (ilmu falak) merupakan salah satu ciri kemajuan peradaban Islam. Namun dalam perjalanannya astronomi Islam hanya mengkaji persoalan-persoalan ibadah, seperti arah kiblat, waktu solat, awal bulan, dan gerhana. Dr. Yahyā Syāmī dalam bukunya yang berjudul 'Ilm al-Falak Șafhạt min al-Turāth al-'Ilmi al- 'Arabì wa al-Islāmī memetakan sejarah perkembangan astronomi Islam menjadi dua 
fasa, iaitu fasa pra-Islam (Mesir Kuno, Mesopotamia, Cina, India, Perancis, dan Yunani) dan fasa Islam. ${ }^{1}$

Fasa Islam ditandai dengan proses penterjemahan karya-karya monumental dari bangsa Yunani ke dalam bahasa Arab. Karyakarya bangsa Yunani yang sangat mempengaruhi perkembangan astronomi di dunia Islam adalah The Sphere in Movement (alKurrah al-Mutaharrikah) karya Antolycus, Ascentions of The Signs (Mațāl'̀ al-Burūj) karya Aratus, Introduction to Astronomy (al-Madkhal ila 'Ilmi al-Falak) karya Hipparchus, dan Almagesty karya Ptolomeus. ${ }^{2}$

Pada ketika itu, kitab-kitab tersebut tidak hanya diterjemahkan tetapi disusuli melalui penelitian yang lebih mendalam dan akhirnya menghasilkan teori-teori baharu. Dari sini muncul tokoh astronomi Islam dalam kalangan umat Islam yang sangat berpengaruh, iaitu al-Khawarizmi dengan magnum opusnya Kitāb al-Mukhtașar fì Hisāb al-Jabr wa al-Muqābalah. Buku ini sangat mempengaruhi pemikiran cendekiawan-cendekiawan Eropah dan kemudiannya diterjemahkan ke dalam bahasa Latin oleh Robert Chester pada tahun 535 H/ 1140 M dengan tajuk Liber algebras et almucabala, dan pada tahun $1247 \mathrm{H} / 1831 \mathrm{M}$ diterjemahkan ke dalam bahasa Inggeris oleh Frederic Rosen. ${ }^{3}$

Menurut EJ. Brill tahun kelahiran dan kematian al-Khawarizmi tidak diketahui secara tepat. Berdasarkan penelitian H. Suter AlKhawarizmi meninggal sekitar tahun $220 \mathrm{H} / 835 \mathrm{M}$ hingga 230 H/844M, sedangkan menurut CA. Nallino sekitar tahun $232 \mathrm{H}$ (846/847M). ${ }^{4}$ Selain itu juga dinyatakan oleh Muhammad Farid Wajdi bahawa al-Khawarizmi meninggal pada tahun 305 H/917

$1 \quad$ Selengkapnya baca Yahya Syami (1997), 'Ilm al-Falak Șafhāt min al-Turāth al-'Ilmi al-'Arabī wa al-Islāmī, Beirut : Dār al-Fikr al'Arabī, hh. 62-102. Lihat juga Ibrāhīm Hilmi al-Ghurī (2008), AlMausū 'ah al-Falakiyyah, Beirut : Dār al-Syarq al-'Arabī, hh. 1014.

$2 \quad$ Ibid., hh. 124-125.

$3 \quad$ Lihat E. Van Donzel (1994), Islamic Desk Reference, Leiden: E.J. Brill, hh. 213-215. Lihat juga jurnal Islamic Studies, Vol. 41, Number 3, Autmn 2002, h. 494.

4 E.J Brill's (1993), First Encyclopaedia of Islam 1913-1936, Leiden: E.J. Brill, Vol. IV, h. 912. 
M. ${ }^{5}$ Berdasarkan pendapat-pendapat di atas, menurut penulis, pendapat yang lebih mendekati kebenaran adalah pendapat pertama kerana al-Khawarizmi hidup pada masa pemerintahan alMa'mun. ${ }^{6}$

Selain al-Khawarizmi, tokoh-tokoh dari kalangan Islam yang ikut membangun dan mengembangkan astronomi Islam adalah :

1. Abū Ma'syar al-Falakī (wafat 272 H/885 M). Karya-karyanya antara lain adalah Ithbāt al- 'Ulūm dan Hai'ah al-Falak.'

2. Jābir Batan̄̄ (wafat 319 H/931 M), yang telah menetapkan kedudukan bintang. Ia telah menciptakan alat peneropong bintang yang ajaib. Kitabnya yang terkenal Kitāb Ma rifati alMațālı’'al-Burūj Bayna Arba 'i al-Falak. ${ }^{8}$

3. Abū al-Rayhān al-Birūn̄̄ (363 H - 440 H/973 M - /1048 M). Salah satu karyanya ialah al-Qānūn al-Mas 'ūdi (sebuah ensiklopedia astronomi yang dipersembahkan kepada Sultan Mas'ūd Maḥmūd), yang ditulis pada tahun $421 \mathrm{H} / 1030 \mathrm{M}$. Selain ahli dalam ilmu falak, beliau juga menguasai berbagai bidang ilmu lainnya, seperti filsafat, matematik, geografi dan fizik. Menurut Prof. Aḥmad Baiquni, al-Birūn̄̄ adalah orang yang pertama menolak teori Ptolomeus, dan menganggap teori geosentris tidak masuk akal. ${ }^{9}$

4. Al-Farghānī. Seorang ahli astronomi Islam yang berasal dari Farghana, Transoxania, sebuah kota yang terletak di tepi sungai Sardaria, Uzbekistan. Di Barat, semua ahli astronomi pada abad pertengahan mengenalinya dengan sebutan Alfraganus. Nama lengkapnya adalah Abū al-'Abbās Aḥmad bin Muḥammad bin Kathīr al-Farghān̄̄. Hampir semua referensi bersepakat

$5 \quad$ Muhammad Farid Wajdi. Dāirah al-Ma'ārif, jilid 3, h. 792.

6 Lihat M. Natsir Arsyad (1995), Ilmuwan Muslim Sepanjang Sejarah, cet. 4, Bandung: Mizan, hh. 34-35. Lihat juga Hassan Ibrahim Hassan. Sejarah dan Kebudayaan Islam, terjemahan Djahdan Humam (1989), Yogyakarta: Kota Kembang, h. 104.

7 A. Hasjmy (1995), Sejarah Kebudayaan Islam, cet. 5, Jakarta: Bulan Bintang, h. 297.

$8 \quad$ Ibid, h. 298.

9 Ahmad Baiquni (1996), al-Qur'an Ilmu Pengetahuan dan Teknologi, cet. 4, Yogyakarta: Dana Bhakti Prima Yasa, h. 9. 
bahawa al-Farghanī adalah tokoh terkemuka dan seorang ahli astronomi Islam yang hidup semasa Khalifah al-Ma'mun (813833M), hingga masa kematian al-Mutawakkil (847-881M). Karya utamanya yang masih tetap bertahan dalam bahasa Arab masih tersimpan baik di Oxford, Paris, Kaherah dan di Perpustakaan Princeton University dengan judul yang berbezabeza. Di antaranya adalah Jawāmi' 'ilm al-Nujūm wa alHarakah al-Samāwiyyah, Ușul 'Ilm an-Nujūm, al-Madkhal ilā 'Ilm Hayāt al-Falak dan Kitāb al-Fușūl al-Thalāthīn. Semua karya tersebut telahpun diterjemahkan ke dalam bahasa Latin Spanyol oleh John Hispalensis dari Seville dan Gerard dari Cremona pada tahun $899 \mathrm{H} / 1493 \mathrm{M} .{ }^{10}$

5. Nașir al-Dīn al-Ṭūsī (Abū Ja'far Muhammad bin Muḥammad bin al-Hasan Nașir al-Dīn al-Ṭūsī, 598H - 673H/1201M 1274M). " Dalam bidang ini, ia merupakan tokoh yang sangat menonjol di antara ilmuwan dan peneliti Muslim lainnya. Penelitiannya antara lain mengenai "lintasan, ukuran, dan jarak planet Merkurius", "terbit dan terbenam", "ukuran dan jarak matahari dengan bulan", dan kenaikan bintang-bintang". Di antara karya tulisnya dalam bidang ini ialah al-Mutawassit baina al-Handasah wa al-Hai'ah (kumpulan karya terjemahan dari Yunani tentang geometri dan astronomi), al-Tadhkirah fi' ilm al-Hai'ah (sebuah karya hasil penyelidikan dalam bidang astronomi) dan Zubdah al-Hai'ah (intisari Astronomi).

6. Muhammad Turghay Ulughbek (797-853 H/1394-1449 M). Beliau dikenali sebagai pakar astronomi Islam dan membangunkan observatorium di Samarkand pada tahun $823 \mathrm{H} / 1420 \mathrm{M}$ dan menyusun zij Sulțānī. ${ }^{12}$

Karya-karya monumental tersebut sebahagian besarnya masih berupa manuskrip dan kini tersimpan di Ma'had al-Makhțūtât

10 E.J Brill's. First Encyclopaedia of Islam 1913-1936, Vol. 3, h. 67.

11 Lihat Hasan Asari (1994), Menyingkap Zaman Keemasan Islam, Bandung: Mizan, h. 118. Hanya saja pada buku tersebut konversi kalendar syamsiyah dan qamariah kurang tepat. Menurut perhitungan penulis tahun $1274 \mathrm{M}$ sama dengan $673 \mathrm{H}$ sedangkan pada buku tersebut tahun $1274 \mathrm{M}$ sama dengan $672 \mathrm{H}$.

12 John L. Esposito (1995), The Oxford Encyclopedia of The Modern Islamic World, New York: Oxford University Press, hh. 147, 271. 
al- 'Arabī, Kaherah-Mesir. Patut diketahui bahawa semua karyakarya tersebut di atas masih bergaya dan bernuansa geosentris. Ertinya karya-karya tersebut masih banyak dipengaruhi oleh Ptolomeus, yang menempatkan bumi sebagai pusat peredaran planet-planet dan matahari. Asumsi ini didasarkan pada kenyataan sejarah bahawa teori heliosentrik yang dibangun oleh Copernicus baru muncul abad XVI M. Meskipun pada huraian sebelumnya disebutkan al-Birūnī telah mengkritik teori geosentrik.

DiAlam Melayuastronomi Islamjugaberkembang pesat. Ulama yang berjasa mengembangkan astronomi Islam di dunia Melayu (Indonesia-Malaysia) adalah Syeikh Taher Jalaluddin al-Azhari, ${ }^{13}$ (1286-1377H/1869-1957M) dengan karya-karyanya antara lain Pati Kiraan Pada Menentukan Waktu Yang Lima (Singapore : AlAhmadiyyah Press, 1357 H/1938 M) dan Natījah al-Ummi (The Almanac: Muslim and Christian Calender and Direction of Qiblat according to Shafie Sect (Taiping, Perak : Matba'ah al-Zainiyah, 1951). ${ }^{14}$ Di Indonesia selain Syekh Taher Jalaluddin pada masa itu juga ada tokoh-tokoh astronomi Islam yang sangat berpengaruh, seperti Syeikh Ahmad Khatib Minangkabau, ${ }^{15}$ Ahmad Rifai, dan K.H. Sholeh Darat. Selanjutnya perkembangan astronomi

13 Harun Nasution (1992), Ensiklopedi Islam Indonesia, Jakarta: Djambatan, h. 324. Namun menurut Wan Mohd. Shaghir Abdullah sebelum Syeikh Tahir Jalaluddin sudah ada ulama falak yang berperan dalam pengembangan astronomi Islam di Alam Melayu iaitu Raja Muhammad Sa'id bin Raja Muhammad Tahir Riau. Selengkapnya baca Wan Mohd. Shaghir Abdullah, "Kiyai Muhammad Shalih al-Fathani Ahli Falak Nusantara", Utusan Malaysia, 10/10/2005. Diakses melalui Utusan Online, 20 April 2010/ 6 Jamadil Awal $1431 \mathrm{H}$, pukul $9.56 \mathrm{am}$.

14 Abu Bakar Hamzah. "Sheikh Tahir Jalaluddin", Medium Majalah Ilmiah Akademi Islam Universiti Malaya, Tahun 1, Bil. 1, Muharram 1409/September 1988, h. 92.

15 Ulama besar Minangkabau ahli falak wafat di Mekah 8 Jumadil Awal 1334 H/ 1916 M. Karya-karyanya yang berkait dengan ilmu falak adalah al-Jawāhir al-Naqiyyah fì A'māl al-Jaibiyyah (1309 H/1891 M) dan Raudah al-Husāb fì 'Ilm al-Hisāb (1310 H/ 1892 M). Baca Deliar Noer (1980), Gerakan Modern Islam di Indonesia 1900-1942, Jakarta: LP3ES, hh. 38-40. 
Islam di Indonesia dipelopori K.H. Ahmad Dahlan ${ }^{16}$ dan Syekh Muhammad Djamil Djambek (15 Sya'ban 1279-16 Safar 1367 H/ 2 Februari 1862 - 30 Desember 1947 M) ${ }^{17}$ dengan karyanya Diya ${ }^{\text {, }}$ al-Nayirīn fìmā Yata' 'allaqu bi al-Kawākibìn, suatu rentetan tabeltabel mengenai perhitungan waktu. ${ }^{18}$ Kemudian diteruskan oleh anaknya Saadoe'ddin Djambek (1330-1398 H/1911-1977 M). ${ }^{19}$ Untuk mengenang jasa Saadoe'ddin dalam bidang astronomi Islam didirikan laboratorium astronomi Islam di kampus IAIN Syarif Hidayatullah, Ciputat-Jakarta, laboratorium tersebut diberi nama Laboratorium Saadoe'ddin Djambek. ${ }^{20}$ Akan tetapi laboratorium tersebut kini telah tiada kerana impak dari projek pengembangan kampus UIN Syarif Hidayatullah.

Di antara murid-murid Saadoe'ddin yang menjadi tokoh astronomi Islam adalah H. Abdur Rachim. Beliau adalah staf pengajar Fakultas Syari'ah IAIN Sunan Kalijaga Yogyakarta dan Wakil Ketua Badan Hisab dan Rukyat Departemen Agama RI. Jabatan lainnya adalah Ketua Bagian Hisab dan Pengembangan Tafsir Majelis Tarjih dan Pengembangan Pemikiran Islam Pimpinan Pusat Muhammadiyah Periode 1995-2000. Karya-karyanya yang berkaitan dengan ilmu falak di antaranya: Mengapa Bilangan

16 Dalam bidang ilmu falak ia merupakan salah seorang pembaharu, yang meluruskan arah kiblat masjid Agung Yogyakarta pada tahun 1897 M/ 1315 H. Pada saat itu masjid Agung dan masjid-masjid lainnya, letaknya ke barat lurus, tidak tepat menuju arah kiblat yang 24 derajat arah barat laut.

17 Data ini seperti yang termaktub di makam Syekh Jambek sebagaimana diinformasikan oleh H. Fachri Syamsuddin yang berkunjung ke makam Syekh Jamil Jambek pada tanggal 1 Julai 1996. Huraian selengkapnya mengenai Syaikh Jambek lihat Deliar Noer (1985), Gerakan Modern Islam Di Indonesia 1900-1942, cet. 3, Jakarta: LP3ES, hh. 42-44. Lihat juga Hassan Shadiliy (1982), Ensiklopedi Indonesia, Jakarta: Ichtiar Baru, $3: 1531$.

18 Riht B.J.O Schrieke (1973), Pergolakan Agama di Sumatera Barat, Sebuah Sumbangan Bibliografi, (terj.) Soegarda Poerbakawatja, Jakarta : Bhratara, h. 84.

19 Huraian selengkapnyamengenai Saadoe'ddin DjambekbacaSusiknan Azhari (1998), Saadoe'ddin Djambek dan dan Pemikirannya tentang Hisab, Jurnal al-Jami'ah, No. 61 Th. 1998, Yogyakarta: IAIN Sunan Kalijaga, hh. 162-164.

20 Abdul Azis Dahlan. Ensiklopedi Hukum Islam, I : 276. 
Ramadlan 1389 H ditetapkan 30 Hari? (1969), Menghitung Permulaan Tahun Hidjrah (1970), Ufuq Mar'i sebagai Lingkaran Pemisah antara Terbit dan Terbenamnya Benda-benda Langit (1970), Ilmu Falak (1983) dan Kalender Internasinal.

Selanjutnya, di Malaysia peranan Syeikh Tahir Jalaluddin dalam pengembangan kajian astronomi Islam juga sangat besar. Untuk mengenang jasa beliau didirikan Pusat Falak Syeikh Tahir di Balik Pulau Pantai Acheh, Pulau Pinang Malaysia. ${ }^{21}$ Tokoh lain yang berjasa dalam pengembangan kajian astronomi Islam di Malaysia, iaitu Syeikh Abdullah Fahim beliau adalah datuk mantan Perdana Menteri Malaysia Tun Dato' Abdullah Ahmad Badawi. Salah satu jasa beliau terbesar bagi Malaysia adalah menentukan tanggal kemerdekaan Negara Malaysia (31 Ogos 1957). Beliau belajar astronomi Islam dari Syeikh Ahmad Al-Fathani kemudian kepada Syeikh Muhammad Nur bin Syeikh Muhammad. Tokoh astronomi Islam semasa dengannya adalah Haji Umar (Kelantan), Haji Abu Bakar bin Haji Hasan (Johor), dan Syeikh Jamil Jambek (Indonesia). ${ }^{22}$

Tokoh lain yang turut membangun dan mengembangkan astronomi Islam di Malaysia adalah Tuan Haji Moh. Khair bin Hj. Mohd Taib (8 September 1922 - 28 Oktober 1989). Beliau merupakan salah seorang yang mengasaskan Persatuan Falak Syarie Malaysia (7 Oktober 1983). Berdirinya perkumpulan ini dimaksudkan untuk mengumpulkan semua pakar dan peminat ilmu astronomi Islam dan medan bertukar-tulis fikiran. ${ }^{23}$ Setelah Tuan Haji Moh. Khair Taib meninggal dunia pengembangan kajian astronomi Islam dilanjutkan oleh Tuan Guru Tuan Haji Ab. Rahman b. Hussain. Jika Mohd Khair Taib berjasa dalam menubuhkan Persatuan Falak Syar'i Malaysia (PFSM), Ab. Rahman b. Hussain berjasa dalam memimpin PFSM. Beliau mula memimpin PFSM sebagai Yang DiPertua selama 14 tahun sejak dari Oktober 1992

21 Pusat pengajian falak ini dibuka secara rasmi pada hari Rabu, 30 Rabiul Awal 1412 H bersamaan 9 Oktober 1991M. Selengkapnya lihat www.mufti-penang.gov.my

22 Baca Tajuddin Saman dan Ab. Manaf Haji Ahmad (2006), TokohTokoh Agama dan Kemerdekaan Di Alam Melayu, cet. 2, Kuala Lumpur :Yayasan Dakwah Islamiah Malaysia, hh. 122-125.

$\underline{23}$ Lihat www.wikipedia.org. diakses tanggal 12 April 2010, pukul 2.32 pm. 
hingga akhir hayatnya, September 2006. Beliau mengambil alih tampok kepimpinan PFSM selepas Dr. Abdullah Ibrahim melepas jawatan sebagai Yang DiPertua yang pertama kerana bertugas di Negara Brunei Darussalam pada Oktober 1992.

Ab. Rahman Hussein merupakan tokoh astronomi Islam yang sangat terkenal terutama di Kelantan kerana nama beliau selalu tercantum di kalender dan diari agensi kerajaan negeri Kelantan sebagai "hasib" jadual waktu solat dan takwim Hijri. ${ }^{24}$ Oleh kerana itu kepergiannya menyisakan duka yang mendalam bagi masyarakat Muslim Malaysia terutama bagi pihak-pihak yang terlibat dalam pengembangan kajian astronomi Islam.

Selanjutnya literatur-literatur astronomi Islam yang berkembang dan banyak digunakan di Indonesia dan Malaysia di antaranya sebagai berikut :

1. Sullām al-Nayyirain oleh Muhammad Mansur bin Abdul Hamid, Jakarta.

2. Fath Rauf al-Mannān oleh Abu Hamdan Abdul Jalil, Kudus

3. Al-Durūs al-Falakiyyah oleh Ma'sum bin Ali, Jombang

4. Badī’ah al-Mithāl oleh Ma'sum bin Ali, Jombang

5. Al-Qawā'id al-Falakiyyah oleh Abdul Fatah at-Tukhi, Mesir

6. Al-Mațla‘ al-Sa'īd oleh Husain Zaid, Mesir

7. Al-Khulāṣah al-Wāfiyah oleh Zubair Umar al-Jailani, Salatiga

8. Hisab Urfi dan Hakiki oleh KRT Wardan Diponingrat, Yogyakarta

9. Waktu dan Djadwal oleh Saadoe'ddin Djambek, Jakarta

10. Almanak Djamiliyah oleh Saadoe'ddin Djambek, Jakarta

11. Arah Kiblat oleh Saadoe'ddin Djambek, Jakarta

12. Perbandingan Tarich oleh Saadoe'ddin Djambek, Jakarta

24 Lihat www.falaksyari.org, diakses tanggal 19 April 2010, pukul 4.15 pm. 
13. Pedoman Waktu Sholat oleh Saadoe'ddin Djambek, Jakarta

14. Sholat dan Puasa di Daerah Kutub oleh Saadoe'ddin Djambek

15. Hisab Awal Bulan oleh Saadoe'ddin Djambek, Jakarta

16. Ilmoe Falak oleh Siradj Dahlan, Yogyakarta

17. Ilmu Falak oleh Abdur Rachim, Yogyakarta

18. Ilmu Falak oleh Salamun Ibrahim, Lamongan

19. Ephemeris Hisab Rukyat oleh Departemen Agama RI

20. Nurul Anwar oleh K.H. Noor Ahmad SS

21. 'Ilm al-Falak wa al-Taqāwīm oleh Muhammad Basil atTa'i, Mesir.

22. Taqwim Hijriyyah Khairiyyah oleh Haji Md. Khair Haji Md Taib, Malaysia

23. A Moden Guide to Astronomical Calculations of Islamic Calendar, Times \& Qibla oleh Mohammad Ilyas, Malaysia

24. Kalender Islam Antarbangsa oleh Mohammad Ilyas, Malaysia

25. Islamic Astronomy and Science Development Glorious Past, Challenging Future oleh Mohammad Ilyas, Malaysia

26. Ilmu Falak oleh Baharrudin Zainal, Malaysia

27. Kaedah Penentuan Awal Ramadhan, Syawal dan Zulhijjah di Malaysia oleh JAKIM, Malaysia

28. Qāmūs Dār al-'Ilmi al-Falaki oleh 'Abd al-'Amir Mu'min, Irak.

\section{DINAMIKA KAJIAN ASTRONOMI ISLAM DI ALAM MELAYU: KES INDONESIA DAN MALAYSIA}

Perkembangan kajian astronomi Islam di Indonesia mengalami pasang surut sesuai perkembangan zaman. Di Indonesia astronomi Islam diajarkan di pondok-pondok pesantren, Madrasah 
Mu'allimin Muhammadiyah, Pendidikan Ulama Tarjih, dan Perguruan Tinggi Islam. Di pondok pesantren kajian astronomi Islam lebih banyak menggunapakai kitab-kitab astronomi Islam tradisional, sedangkan di Madrasah Muallimin Muhammadiyah dan Pendidikan Ulama Tarjih lebih banyak menggunapakai kitabkitab astronomi Islam moden. Sementara itu di Perguruan Tinggi Islam baik swasta maupun negeri berusaha memadukan khazanah Islam dan sains moden.

Perlu diketahui perkembangan astronomi Islam semakin diperhatikan masyarakat ketika terjadi perbezaan dalam penentuan awal bulan Ramadan, Syawal, dan Dhulhijah. Pada saat itu masyarakat muslim berasa ingin tahu mengapa muncul perbezaan. Tulisan-tulisan berkaitan astronomi Islam bermunculan di media massa baik lokal maupun nasional dengan menggunapakai berbagai perspektif, seperti Penyeragaman Kalender Islam Sebuah Harapan ${ }^{25}$ dan Penyatuan Kalender Islam Tantangan Dunia Astronomi, Fuqaha, dan ahli Rukyat. ${ }^{26}$

Menyedari akan pentingnya astronomi Islam pemerintah Indonesia melalui Departemen Agama $\mathrm{RI}^{27}$ memasukkan ilmu astronomi Islam sebagai kurikulum nasional. Ertinya mata kuliah ilmu astronomi Islam wajib diberikan seluruh Perguruan Tinggi Islam di Indonesia, khasnya yang memiliki fakultas Syari'ah. Bahkan dibuka program khas astronomi Islam S1, S2, dan S3 dalam rangka memadukan khazanah Islam dan sains moden. Selanjutnya untuk mengetahui perkembangan ilmu astronomi Islam di Indonesia, di sini dilaporkan hasil penelitian yang dilakukan oleh mahasiswa IAIN/UIN Sunan Kalijaga Yogyakarta dan IAIN/UIN Syarif Hidayatullah Jakarta. Kedua Perguruan Tinggi Islam ini merupakan Perguruan Tinggi Islam tertua dan terbesar di Indonesia.

Hasil penelitian menyimpulkan bahawa sejak tahun 1966 sampai 2007 telah dilakukan penelitian berkaitan astronomi Islam sejumlah 107 mahasiswa (Awal Bulan kamariah = 86 orang, arah

\footnotetext{
25 Selengkapnya lihat majalah Risalah, No. 3/XXXI Juli 1993.

26 Lihat Republika

27 Sejak Pemerintahan Susilo Bambang Yudhono periode 2009-2014 (Kabinet Indonesia Bersatu Jilid II) diubah menjadi Kemeterian Agama RI.
} 
kiblat $=14$ orang, dan awal waktu salat $=7$ orang). Di IAIN/UIN Syarif Hidayatullah Jakarta permasalahan astronomi Islam yang banyak diteliti adalah awal bulan kamariah, awal waktu salat, dan arah kiblat. Khas di IAIN/UIN Sunan Kalijaga Yogyakarta sampai tahun 2004 aspek kajian astronomi Islam hanya berkisar awal bulan kamariah dan awal waktu salat. Penelitian-penelitian yang dilakukan lebih bersifat teoritis-filosofis.

Dalam perkembangannya, di Indonesia berdiri Badan Hisab Rukyat yang memiliki perhatian terhadap astronomi Islam. Lembaga ini dibentuk oleh pemerintah (Departmen Agama RI) yang bertugas untuk memberikan masukan dan saran kepada Menteri Agama dalam penetapan awal Ramadan, Syawal dan Dhulhijah. Setiap tahun lembaga ini melakukan musyawarah kerja yang dihadiri berbagai pakar astronomi Islam di Indonesia. Pertemuan ini membahaskan hasil perhitungan hisab dari berbagai aliran yang berkembang di Indonesia. Untuk lebih jelasnya perhatikan tabel berikut ini.

Data Hisab Menjelang Syawal $1432 \mathbf{H}^{28}$

\begin{tabular}{|c|c|c|c|c|c|}
\hline \multirow[b]{2}{*}{ No } & \multirow[b]{2}{*}{ Sistem } & \multicolumn{3}{|c|}{ Ijtimak } & \multirow{2}{*}{$\begin{array}{l}\text { Tinggi } \\
\text { Hilal }\end{array}$} \\
\hline & & Hari & Tanggal & Jam & \\
\hline 1 & $\begin{array}{l}\text { Sullām al- } \\
\text { Nayyirain }\end{array}$ & Senin & $29 / 08 / 2011$ & 09:57:00 & $04^{\circ} 01^{\prime} 30^{\prime \prime}$ \\
\hline 2 & $\begin{array}{l}\text { Fath al-Rauf al- } \\
\text { Mannān }\end{array}$ & Senin & $29 / 08 / 2011$ & $11: 01: 00$ & $03^{\circ} 30^{\prime} 30^{\prime \prime}$ \\
\hline 3 & $\begin{array}{l}\text { Qawā'id al- } \\
\text { Falakiyyah }\end{array}$ & Senin & $29 / 08 / 2011$ & 10:09:00 & $02^{\circ} 49^{\prime} 00^{\prime \prime}$ \\
\hline 4 & Badī‘ah al-Mithāl & Senin & $29 / 08 / 2011$ & $10: 04: 18$ & $01^{\circ} 55^{\prime} 08^{\prime \prime}$ \\
\hline 5 & Jean Meaus & Senin & $29 / 08 / 2011$ & 09:58:00 & $02^{\circ} 16^{\prime} 35^{\prime \prime}$ \\
\hline 6 & $\begin{array}{l}\text { Ittifāq Zāti al- } \\
\text { Bain }\end{array}$ & Senin & $29 / 08 / 2011$ & $09: 58: 24$ & $05^{\circ} 03^{\prime} 43^{\prime \prime}$ \\
\hline 7 & Mațla’ al-Sa‘̄id & Senin & $29 / 08 / 2011$ & $10: 04: 18$ & $02^{\circ} 10^{\prime} 10^{\prime \prime}$ \\
\hline 8 & Ephemeris & Senin & $29 / 08 / 2011$ & $10: 05: 00$ & $02^{\circ} 06^{\prime} 00^{\prime \prime}$ \\
\hline 9 & New Comb & Senin & $29 / 08 / 2011$ & $09: 57: 50$ & $01^{\circ} 58^{\prime} 32^{\prime \prime}$ \\
\hline 10 & Nūr al-Anwār & Senin & $29 / 08 / 2011$ & 09:57:00 & $03^{\circ} 04^{\prime} 00^{\prime \prime}$ \\
\hline
\end{tabular}

28 Sumber: Keputusan Temu Kerja Evaluasi Hisab Rukyat Tahun 2009, Direktorat Urusan Agama Islam dan Pembinaan Syari'ahDirjen Bimas Islam Depag RI. 


\begin{tabular}{llllll}
11 & $\begin{array}{l}\text { Khulāșah al- } \\
\text { Wāfiyyah }\end{array}$ & Senin & $29 / 08 / 2011$ & $10: 05: 03$ & $01^{\circ} 299^{\prime} 30^{\prime \prime}$ \\
12 & Mawāqit & Senin & $29 / 08 / 2011$ & $10: 04: 02$ & $01^{\circ} 31^{\prime} 00^{\prime \prime}$ \\
13 & Hisab Hakiki & Senin & $29 / 08 / 2011$ & $10: 04: 03$ & $01^{\circ} 49^{\prime} 19^{\prime \prime}$ \\
14 & Ascript & Senin & $29 / 08 / 2011$ & $10: 04: 00$ & $01^{\circ} 10^{\prime} 23 ”$ \\
\hline
\end{tabular}

Hasil musyawarah ini kemudian diserahkan kepada Menteri Agama sebagai bahan untuk menetapkan awal Ramadan, Syawal, dan Dhulhijah. Patut dicatat pula, selain Badan Hisab Rukyat milik pemerintah juga berkembang pusat-pusat kajian falak di ormasormas Islam di Indonesia, seperti Muhammadiyah, Nahdlatul Ulama, Persatuan Islam, dan Dewan Da'wah Islam Indonesia. Bahkan organisasi masyarakat Islam ini memiliki kalender Hijriah sendiri sesuai dengan metodologi yang digunapakai dalam penetapan awal bulan kamariah.

Selain lembaga formal, kajian astronomi Islam di Indonesia juga dikembangkan oleh kelompok-kelompok amatur, seperti Rukyatul Hilal Indonesia (RHI). Lembaga ini didirikan pada tanggal 1 Muharam $1427 \mathrm{H}$ atau bertepatan dengan 31 Januari 2006 di Yogyakarta. Mempelopori pembentukan RHI ini adalah Mutoha Arkanuddin ketua Jogja Astro Club (JAC) sebuah komuniti astronom amatur di Yogyakarta. Pada awalnya RHI hanya merupakan kelompok diskusi online (mailing list) tentang permasalahan yang terkait dengan astronomi Islam yang beralamat di Milis RHI. Kelompok diskusi online ini hingga kini memiliki lebih 300 anggota yang tersebar di seluruh pelosok Indonesia. Sejalan dengan perkembangan milis ini akhirnya berkembang menjadi komunitas darat yang sering berkumpul untuk berdiskusi dan melakukan observasi lapangan yang dilakukan setiap menjelang awal bulan kamariah.

Pada usianya yang ke-3, tepatnya tanggal 13 Disember 2008, RHI secara rasmi berdaftar dan menjadi lembaga yang diberi nama Lembaga Pengkajian dan Pengembangan Ilmu Falak (LP2IF) Rukyatul Hilal Indonesia. Hal ini berdasarkan Akta Notaris yang dikeluarkan oleh Notaris Nurhadi Darussalam, S.H., M.Hum dengan terbitnya Surat Akta Nomor : 02/Tanggal 13 Desember 2008. ${ }^{29}$ Kelompok Kajian astronomi Islam yang lain adalah

29 www.rukyatulhilal.org. diakses hari Jumaat 16 April 2010, pukul $4.29 \mathrm{pm}$. 
CASA (Club Astronomi Santri Assalam) berdiri bersempena dengan salah satu event besar Astronomi Dunia yakni AstroDay 2005 yang diperingati di Assalaam pada Sabtu, 16 April 2005, bertempat di kantor Assalaam lantai II. Pendiri CASA adalah AR Sugeng Riyadi dan Budi Prasetyo. ${ }^{30}$

Muhammadiyah sebagai organisasi Islam tertua dan terbesar serta peletak dasar penggunaan astronomi Islam dalam penentuan awal bulan kamariah di Indonesia juga tidak ketinggalan. Pada tanggal 8 Rabi'ul akhir 1428 H/ 26 April 2007 mendirikan Pusat Kajian Falak yang berusaha memadukan khazanah Islam dan sains moden. Merasmikan Pusat kajian ini Prof. Dr. Din Syamsuddin Ketua Umum Pimpinan Pusat Muhammadiyah pada saat sidang Tanwir Muhammadiyah di Hotel Garuda Yogyakarta. Pusat kajian ini berusaha memberikan informasi sekitar astronomi Islam melalui pelatihan, kajian, dan survei literatur terbaru di bidang astronomi Islam. ${ }^{31}$ Selain lembaga-lembaga tersebut di Indonesia masih banyak pusat-pusat kajian astronomi Islam bermunculan baik yang bersifat individual maupun kolektif. ${ }^{32}$

Sementara itu di Malaysia perkembangan kajian astronomi Islam juga mengalami perkembangan yang sangat menggembirakan. Dengan menggalakkan pelatihan-pelatihan, pameran, dan seminar. Bahkan di Jabatan Fiqh dan Usul Akademi Pengajian Islam Universiti Malaya mengadakan program khas falak syar'i yang berusaha memadukan antara falak syar'i dan falak ilmi. Begitu pula di Universiti Darul Iman Malaysia dibuka Ijazah Pasca Siswazah Astronomi Islam. Adapun tokoh-tokoh yang memiliki perhatian dalam bidang astronomi Islam, di antaranya Prof. Dr. Mohammad Ilyas (USM), Syed Kamarulzaman (Ketua Persatuan Falak Syar'i Malaysia), Prof. Dr. Mohd. Zambri Zainuddin(Penyelaras Program Falak Jabatan Fizik Universiti Malaya), Dr. Kassim Bahali (Balai Cerap Al-Khawarizmi), Dr. Baharrudin Zainal (KUSZA), dan Dr. Ibnor Azli bin Ibrahim (Universiti Kebangsaan Malaysia).

30 www.blogcasa.wordpress.com, diakses hari Jumaat 16 April 2010, pukul $4.34 \mathrm{pm}$.

31 www.ilmufalak.or.id, diakses hari Jumaat 16 April 2010, pukul 4.40 pm.

32 Pusat-pusat pengajian yang dimaksudkan antara lain Bengkel Falak, Falak Persis, Langit Selatan, dan Komunitas Falak Perempuan Indonesia. 
Semasa pengkajian dilakukan, sejak tahun 2001-2010 ditemui tujuh belas tajuk penelitian mengenai astronomi Islam telah dilakukan. ${ }^{33}$ Tema penelitiannya adalah seputar awal waktu solat, arah kiblat, awal bulan kamariah, dan lembaga astronomi Islam di Malaysia. Penelitian-penelitian yang dilakukan bersifat teoritis-implementatif. Tema kajiannya pun sangat aktual dan menarik. Salah satu contohnya adalah penelitian yang dilakukan Radzuan bin Nordin yang menghubungkan antara persoalan takwim hijri dan zakat. Selama ini masyarakat Muslim Malaysia khasnya dan masyarakat Muslim 'amnya tidak sedar bahawa penggunaan takwim dalam zakat memiliki konsekuensi yang luar biasa. Bukti yang jelas ialah pembayaran zakat perniagaan yang telah ditunaikan oleh Tenaga Nasional Berhad (TNB) bagi tahun kewangan berakhir 2007/2008. Bagi tahun tersebut bayaran zakat perniagaan adalah dikira berdasarkan keuntungan perniagaan sebanyak RM 156,525.48 dan takwim yang digunapakai ialah takwim Masihi. ${ }^{34}$ Seharusnya jika menggunapakai takwim Masihi zakat yang wajib ditunaikan ialah RM 161,346.4647. Perbezaan bayaran ialah RM 4,820.9847. ${ }^{35}$ Begitu pula penelitian yang dilakukan oleh Ahmad Kamil b Othman dan Mohd Paidi B Norman dengan tema "Penentuan Waktu Solat Dalam Kapal Terbang". Hasil penelitian ini sangat bermanfaat bagi industri penerbangan khasnya Malaysian Airlines yang menjadi fokus kajian.

Di Malaysia pengembangan kajian astronomi Islam telah pun mendapat perhatian daripada pihak kerajaan, terutamanya Jabatan Kemajuan Islam Malaysia (JAKIM) dan jabatan mufti negeri-negeri. Berbagai laman web yang berkaitan dengan kajian astronomi Islam ditubuhkan. Sehingga ianya dapat memberikan kefahaman kepada masyarakat mengenai isu-isu berkaitan

33 Data bersumber dari Jabatan Fiqh dan Usul Akademi Pengajian Islam Universiti Malaya, FPI Universiti Kebangsaan Malaysia, dan temubual dengan Dr. Ibnor Azli bin Ibrahim pada 25 Februari 2010, pukul $01.00 \mathrm{pm}$.

34 Lihat "TNB bayar zakat perniagaan RM 156,525.48", dimuat dalam harian Utusan Malaysia, 28 hb. Mei 2009.

35 Jika menggunakan Takwim Masihi $=$ RM 6,261 $019.200 \times 2.577 \%$ $=\mathrm{RM} 161,346.4647$. Takwim Hijri $=\mathrm{RM} 6,261019.200 \times 2.5 \%=$ RM 156,525.48. Perbezaan bayaran zakat $=$ RM 161,346.4647 - RM $156,525.48=\mathrm{RM} 4,820.9847$ 
astronomi Islam. Laman web astronomi Islam JAKIM dan Jabatan Mufti Negeri Selangor merupakan laman web yang senantiasa memberikan informasi seputar tuntutan dan pengamalan astronomi Islam berhubungkait dengan persoalan ibadah, seperti bagaimana cara menghitung awal waktu solat, menentu dan mengesahkan arah kiblat, dan jadual pencerapan anak bulan. ${ }^{36}$ Sementara itu laman web al-Azim yang ditubuhkan oleh Jabatan Mufti Melaka lebih dinamis menginformasikan seputar astronomi Islam, khasnya aktiviti Balai Cerap Al-Khwarizmi yang berlokasi di Tanjung Bidara, Melaka. Hal senada juga dilakukan oleh Unit Falak Fakulti Pengajian Kontemporari Islam Universiti Darul Iman Malaysia ${ }^{37}$ dan Pusat Falak Syeikh Taher.

Selain itu berbagai laman web astronomi Islam oleh individu mahupun organisasi juga mulai ditubuhkan. Falakonline yang ditubuhkan oleh Shahrin Bin Haji Ahmad pada tahun 1999 merupakan laman web yang sangat kreatif-dinamis. Menurut Shahrin laman web ini bertujuan utama untuk sama-sama belajar, berkongsi pengalaman, penyebaran berita terkini, dan perbincangan isu. Sesuai tujuannya laman web ini senantiasa memaklumkan berita terbaharu. Seperti berita pada hari Jumaat 2 April 2010 yang menginformasikan himpunan Zuhrah dan Utarid. Dalam laman web ini dikhabarkan pula pelbagai aktiviti astronomi Islam. Namun pautan yang ditunjukkan hanyalah pautan serantau, manakala laman web antara bangsa tidak dimaklumkan. ${ }^{38}$

Tidak ketinggalan Persatuan Falak Syar'i Malaysia juga menubuhkan laman web tentang astronomi Islam. Laman web ini dirasmikan pada seminar astronomi Islam dengan tema "Ilmu Falak Menyongsong Zaman, Menjana Tamadun" pada 14 Julai di kampus Universiti Tenaga Nasional (UNITEN), Bangi, Selangor, Malaysia. Kehadiran laman web ini juga sangat membantu mempromosikan isu-isu baharu seputar astronomi Islam. Sejak 1 Januari 2008 hingga kini laman web ini telah diakses oleh seramai 21851 orang dari berbagai negara, seperti Mesir, Arab Saudi, Syria, Kuwait, Indonesia, Singapore, Amerika Syarikat,

36 Perhatikan www.islam.gov.my dan www.muftiselangor.gov.my.

37 Laman web ini telah online sejak 1997. Pengunjung sejak 1 Ramadan hingga kini sebanyak 56030, diakses pada hari Kamis, 22 April 2010 pukul 10.42 am.

38 Sila kunjungi www.falak-online.net 
Brazil, Inggris, dan Nigeria. Masyarakat Malaysia yang pernah melayari laman web falak syar'i seramai 19844 orang. Manakala masyarakat luar negara yang tercatat telah mengakses laman web ini seramai lebih dari seratus orang iaitu Amerika Syarikat seramai 526 orang, Indonesia seramai 261 orang, Arab Saudi seramai 233, dan Mesir seramai $109 .{ }^{39}$ Hal ini menunjukkan bahawa kehadiran laman web ini sangat diminati tidak hanya dalam negara tapi juga antarbangsa.

Selain laman web tersebut, kajian astronomi Islam di Malaysia juga dikembangkan di Planetarium Negara, Unit Penyelidikan Ilmu Falak \& Sains Atmosfera Universiti Sains Malaysia, Planetarium Sultan Iskandar Sarawak, Observatorium Mini Dr. Rowi, dan Jabatan Fizik Universiti Malaya. Setiap awal bulan kamariah Jabatan Fizik Universiti Malaya melakukan observasi hilal di Teluk Kemang Port Dikcson Negeri Sembilan Malaysia. Hasil observasi ini sangat berguna untuk membangunkan teori baharu dalam penentuan awal bulan kamariah di masa hadapan.

\section{PENUTUP}

Berdasarkan huraian di atas dapat dinyatakan bahawa perkembangan kajian astronomi Islam di Alam Melayu khasnya Indonesia dan Malaysia tidak dapat dipisahkan dari peranan penting tokoh-tokoh awal, seperti Ahmad al-Fathani dan Syeikh Tahir Jalaluddin. Penelitian-penelitian astronomi Islam di Indonesia lebih bercorak teoritis-filosofis, sedangkan penelitianpenelitian astronomi Islam di Malaysia lebih bercorak teoritisimplementatif. Di masa hadapan perlu dibangun kerjasama yang saling menguntungkan (mutual benefit) antara Indonesia dan Malaysia dalam rangka mempromosikan wajah astronomi Islam Alam Melayu di peringkat antara bangsa. Oleh kerana itu sudah saatnya Indonesia dan Malaysia merumuskan 'master plan" bersama kajian astronomi Islam untuk menjawab isu-isu sekitar kawasan dan global guna mewujudkan kejayaan Islam kembali dengan memadukan tuntutan agama dan sains.

39 Lihat www.falaksyari.org. diakses hari Khamis 22 April 2010 pukul $12.34 \mathrm{pm}$. 
Jurnal Fiqh, No. 7 (2010) 167-184 